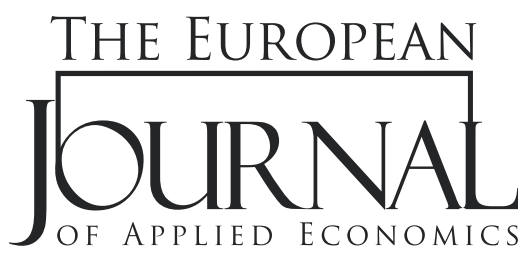

\title{
THE IMPACT OF THE METACOGNITIVE AND BEHAVIORAL FACTORS OF CULTURAL INTELLIGENCE ON FOREIGN BRAND ACCEPTANCE
}

\author{
Stefan Zdravković*, Jelena Peković \\ University of Kragujevac, \\ Faculty of Economics, \\ Kragujevac, Serbia
}

\begin{abstract}
:
The aim of the paper is to show the influence of cultural intelligence in the acceptance of foreign brands and how these insights can help multinational companies in shaping and presenting their brands so that they are better accepted in different cultural environments. Cultural intelligence consists of four factors, two of which have been analyzed for the purposes of this paper - the metacognitive and behavioral factors. The metacognitive cultural dimensions are usefulfor the individual uses to obtain certain knowledge about a culture. Behavioral cultural intelligence represents the ability to adapt an individual to verbal and non-verbal behaviors according to the situation in culturally diverse environments. The results of the empirical research proved a statistically significant positive impact of the behavioral element of cultural intelligence on the acceptance of foreign brands by consumers, while the influence of the metacognitive factor on the acceptance of foreign brands is not statistically significant, which is different from most of the empirical studies conducted so far.
\end{abstract}

Article info:

Received: May 18, 2020

Correction: July 28, 2020

Accepted: October 23, 2020

\section{Keywords:}

cultural intelligence, metacognitive factor, behavioral factor, foreign brand.

\section{JEL Classification:}

D91, Z13

\section{INTRODUCTION}

Globalization is an integral part of human life today. The rise of cultural diversity has led to changes in people's lives and in work organizations, making the world not so simple and superficial. The term cultural intelligence is most often mentioned in the context of multinational companies. Research shows that the high level of development of cultural intelligence is a very important factor within multinational companies, where employees come from different cultural backgrounds, which increases innovation and creativity and contributes to achieving better financial performance of the company. On the other hand, within schools and faculties, pupils and students develop their level of cultural intelligence through certain programs such as exchange, travel and learning a foreign language, which ultimately increases their level of education (Hu et al., 2017). 
Important part of management research is understanding how people from different backgrounds can work through their differences. The rapid globalization has led to a growing group of employees facing challenges and obstacles in their everyday work. Organizationsare required to appear with a new type of manager who is capable of understanding divergence at the surface level, in order to become outstanding in this day economy. Managers who have a high degree of cultural intelligence can positively influence the company's financial performance with their skills and ideas (Alshaibani \& Bakir, 2017). Although we understand the benefits of having this type of manager, little research has been conducted on this topic until the early 21st century. Ang \& Van Dyne (2015) state that cultural intelligence will have an increasing influence in multinational companies and that there is a need for more research in this field in the literature.

The notion of cultural intelligence is particularly salient in multinational companies in two aspects. The first aspect is represented by employees coming from culturally diverse backgrounds. Globalization has imposed the need for employees to have the skills and experience to work in culturally diverse environments. The second aspect represents the operations of companies in the international market, where they present their brands to consumers from different cultures (Aldhaheri, 2017). Consumers are influenced by many of the psychological, social, and personal factors that shape their perception of the brand. A brand can be defined as a label, logo, character, or any other function that identifies and distinguishes one seller from other sellers. Consumers often choose to buy global brands such as CocaCola (Iversen \& Hem, 2011). An important segment that influences consumer perception of a brand is cultural intelligence. Consumers who exhibit high levels of consumer ethnocentrism and low levels of cultural intelligence (which allows for the ability and flexibility to embrace cultural diversity) are averse to everything that comes from other cultures, and therefore to brands (Han \& Guo, 2018; Pratono \& Arli, 2020). On the other hand, a high degree of consumer cultural intelligence has a conclusive result on the acceptance of foreign brands (Ang \& Van Dyne, 2015; Frias-Jamilena et al., 2018b).

Ang \& Van Dyne (2015) state that cultural intelligence is composed of four factors: metacognitive, cognitive, motivational and behavioral. Metacognitive factor is a term referring to a higher thinking ability to obtain knowledge and control over a cognitive factor, which represents knowledge of cultural dissimilarities. Motivational factor is ability to encourage efforts to function in international circumstances, and behavioral factor represents ability to flexibly behave in international interactions (Ang et al., 2007). In other words, cognitive and meta-cognitive factors are of a cognitive nature, while motivational and behavioral factors are of an emotional nature.

Considering the fact that the consumer behavior process is an extremely complex marketing concept and is influenced by many factors, the subject of the research is to test the effect of metacognitive and behavioral cultural intelligence on the acceptance of foreign brands by consumers. The primarily goal of the paper is to regulate whether the metacognitive and behavioral factors of cultural intelligence exert a statistically significant influence on consumers' decision to accept foreign brands. In addition, the paper examines whether the behavioral factor of cultural intelligence is more pronounced in men than in women. Based on multiple regression analysis and $\mathrm{T}$ test for two independent samples, a decision will be made to confirm or reject the research hypotheses. 


\section{LITERATURE REVIEW}

\section{Concept of Cultural Intelligence}

Cultural intelligence can be explained as the capacity to function in a diverse environment since cultural interconnection is a widespread distinction of people's lives (Thomas \& Van Dyne, 2018). Also, cultural intelligence emphasizes a person's prospective to be successful in an extensive range of cross-cultural circumstances and increases an individual's ability to adapt quickly to new cultural settings (Afsar et al., 2019).

Cultural intelligence is often identified with social and emotional intelligence and is indistinguishable to social and emotional intelligence because it is a form of mutual experiences. Social intelligence implies the ability to understand other people. On the other hand, a person who owns high level of emotional intelligence comprehends what is the meaning to be a human and at the same time what makes us so different (Moon, 2010). Cultural intelligence is linked to social and emotional intelligence, but it studies and explores individuals, groups of people, and relationships between them from a different perspective. Thus, a person with a high degree of emotional or social intelligence occasionally possess a high of so-called cultural intelligence (Moon, 2010).

Cultural intelligence is alike and different from common cognitive capacity. Overall cognitive capacity is a key predictor of performance in all jobs and settings. The difference with common cognitive capacity is that this capacity involves only cognitive intellect and excludes motivation, behavior, and metacognitive. Empirical evidence indicates that cultural intelligence is associated with given production in an inter relational context than with contingent ability. Thus, cultural intelligence is gradually increasing by predicting production in intercultural circumstances above general cognitive capacity (Ang et al., 2007).

The influence of cultural intelligence manifests itself in various aspects. Helen Kurpis \& Hunter (2017) point out that is necessary for the management of a company to consist of people who come from different cultures. Management conceived in such a way is highly creative, innovative and can give interesting business ideas that can improve the company's position in the market, and in financial terms. Also, the study points out that is necessary to increase the level of cultural intelligence in students through activities such as exchange. Students can go to another country, meet other cultures, and interact and communicate with people from other cultures. Students achieve numerous benefits, by getting to know other cultures, such as expanding their knowledge, learning foreign languages, increasing their ability to cope in an intercultural environment and the like.

\section{Factors and Method for Measuring Cultural Intelligence}

Cultural intelligence contains four factors: metacognitive, cognitive, motivational, and behavioral (Ang \& Van Dyne, 2015). Metacognitive processes are used to obtain knowledge and awareness of one's cognitive process. People with a higher level of development of metacognitive cultural intelligence can quickly adapt to the values, laws, and regulations of a particular local culture (Tuan, 2016). Cognitive cultural intelligence refers to the specific knowledge of the values and beliefs as well as the economic and legal systems of another culture (Vlajcic et al., 2019).

Motivational factor is ability to encourage efforts to function in international circumstances and establishing interaction with people from other cultures (Jyoti \& Kour, 2015). Managers of companies that have a high degree of motivational cultural intelligence achieve good business performance (Lorenz, Ramsey \& Richey, 2018). People with high levels of motivational cultural intelligence have self-confidence 
and want to interact with people who come from different cultural backgrounds (Li, 2020). The behavioral factor of cultural capacity refers to the demonstration of verbal and non-verbal abilities during the interaction with people from diverse backgrounds (Ang \& Van Dyne, 2015). People with a high degree of behavioral cultural intelligence are very resourceful in intercultural communication (Shaik, Makhecha \& Gouda, 2020). Caputo, Ayoko \& Amoo (2018) emphasize that in order to adapt to a culturally different environment, it is necessary for an individual to possess appropriate verbal, but also non-verbal competencies such as body language, expression of movement and the like. This implies an extensive and flexible threshold for behavior.

Individual differences in cultural intelligence in individuals are measured using a variety of methods, such as the self-report method, the observer report, performance-based measures, and others. The selfassessment method is most commonly used and is based on a list of items applicable to various factors of cultural intelligence (e.g. "I check the accuracy of my cultural knowledge while communicating with people from different cultures"). It has already been mentioned in the paper that cultural intelligence is important from two aspects for multinational companies. Employees need to come from culturally diverse backgrounds and possess a variety of skills, as well as the company's brands to be accepted in foreign markets by consumers. Zhou et al. (2018) in their paper provide an overview of the statements that can be used to check the level of cultural intelligence of employees in a company. Alon et al. (2016) in their work presented a model for measuring business cultural intelligence. Ang et al. (2007) provide an overview of the statements that can be used to check the level of cultural intelligence of consumers. Most of the previous works that have dealt with market research and examining the degree of development of consumer cultural intelligence have used this scale.

\section{Concept of Foreign Brand}

Market globalization plays a crucial role in mitigating the importance of national borders by fostering economic, political, and personal interaction. Due to the process of globalization, the once fractured markets of countries have been notably altered in the following aspects: a) economy - huge investment rate, b) technology - the growth of the Internet and contemporary communication technologies, c) social life - the rise of tourist and business trips in the world (Zabkar et al., 2017). Accordingly, internationally active companies show interest in understanding consumer motivation with respect to reactions to global brands.

Brand can be defined as a name, symbol, logo that differentiates the goods of one seller from the goods of other sellers (Mandler, 2019). Brand value refers to the financial amount of an established brand. It occurs when consumers have two alternative products of the same quality level at their disposal but buy a branded product even though it is more expensive because it reduces the risk when buying (Chailan \& Ille, 2015). Brands make it possible to identify the company's products and services, as well as differentiate them from the competition. They are an effective and persuasive way of communicating the benefits and values that a commodity or assistance can provide. A brand is a guarantee of quality, origin and performance and significantly influences the decision of consumers in the buying process (Mandler, 2019).

In addition to companies, branding can be done by the state and then it is a matter of national branding. Rookwood (2019) questioned how organizing the 2022 FIFA World Cup will affect the image of Qatar's host country. Since this is a planetary, "mega" event, it is expected that most people will follow the events, especially those who love football. 
The state will generate significant revenue from sponsors, TV rights. The arrival of fans will have a positive impact on tourism and hospitality, and in addition, this is an ideal opportunity to present Qatar as a host country in a good light. Branding can also be done at the city level. The study by Kovačić et al. (2019) examined what factors attract tourists to visit Banja Luka. The results showed that tourists are interested in the castle Kastel, which is the oldest historical monument in this city, the river Vrbas. Most tourists point out that they are delighted with Banja Luka kebabs, good nightlife, hospitable people, etc. Also, celebrities can have a positive influence on the image of a city, and famous writer Petar Kočić is a native of Banja Luka. Belgrade can be mentioned as an example of branding at the city level. Foreign tourists most often visit the Kalemegdan Fortress, Aval Tower, the Museum of Yugoslavia, Tasmajdan Park, Knez Mihailova Street and other attractions (Nicic \& Iguman, 2019).

Green branding, which refers to corporate social responsibility and environmental protection, is becoming increasingly popular. "Green marketing" is more popular concept and type of marketing which involves creating Eco products with distinct standards, which allows reducing the negative impact on the environment (Sarkar, 2012). Green marketing activities include reducing waste through reduction and recycling, introducing Eco-friendly packaging, reducing pollution during transport and the like.

\section{Interconnection Between Cultural Intelligence and Acceptance of Foreign Brands}

Using the method of self-evaluation of cultural intelligence, two out of four factors of cultural intelligence were analyzed, metacognitive and behavioral factors. The metacognitive process of cultural intelligence was chosen for analysis because as reported by Ang \& Van Dyne (2015) it represents critical part of cultural intelligence for several reasons: 1) it encourages effective thinking about people and circumstances independently of cultural origination; 2) it is the driver of active change in the person as opposed to the rigid view of culturally limited thinking and assumptions; 3 ) guide the individual towards adapting and revising their own strategies that will be more appropriate in accepting desired outcomes during intercultural encounters. It is also a metacognitive factor as a central part of cultural intelligence that allows for the adaptability, resourcefulness, and flexibility of the individual in the new cultural environment. Taking into account previous empirical research, the meta-cognitive factor of cultural intelligence is one that should facilitate the acceptance of foreign brands, i.e. brands that come from other cultures, and the goal was to analyze whether it influences and to what extent the acceptance of foreign brands.

The behavioral factor of cultural intelligence increases social interplay and focuses on people's will and its ability to alter his or her conduct to adapt to cultural diversity. The importance of behavioral economics is borne out by the fact that psychologist Daniel Kahneman and economist Vernon Lomax Smith received the Nobel Prize in Economics in 2002 - Kahneman for incorporating psychological research into economic science, especially in the fields of human action and risk-taking decision making, and Vernon for introducing laboratory experiments into empirical economic analysis. The impact and importance of the behavioral economy is also reflected in the fact that Kahneman was one of the members of the current presidential election team. Because of the actuality and importance of behavioralism in the world of psychology, economics and beyond, it was chosen to analyze behavioral factor as well as the metacognitive factor of cultural intelligence and to determine whether it has any influence on the acceptance of foreign brands.

The metacognitive factor of cultural intelligence mirrors a person's mental awareness and consciousness throughout intercultural interconnection. Ang et al. (2007) explain that metacognitive cultural intelligence refers to how people perceive their behavior prior to interaction with individuals 
from divergent cultures. Metacognitive skills can foster out - of - the box thinking by assuming that metacognitively intelligent people are probably more innovative, even in a culturally different setting. Therefore, it is assumed that individuals who are characterized by metacognitive ability will find it easier to accept people, brands, customs and products coming from different cultures. Previous empirical research (Ang \& Van Dyne, 2015) has shown that the metacognitive factor leads people to adjust and amend their own plan of action that will be more suitable in accepting desired outcomes during intercultural encounters. The desired outcome in the case of this research is the acceptance of foreign brands. One of the few empirical studies (Frias-Jamilena et al., 2018b) dealing with the issue of the relationship between cultural intelligence and brands has shown that the acceptance of foreign brands is most influenced by the motivational and behavioral factor of cultural intelligence. Followed by metacognitive factor where a moderate correlation was present, while a low degree of correlation between the two variables was observed for the cognitive factor. Pratono \& Arli (2020) found that there is a positive impact of cultural intelligence on the acceptance of foreign brands. Summarizing the foregoing, and in the context of the research covered in the paper, the first hypothesis can be formulated:

H1: The metacognitive factor of cultural intelligence has a positive statistically significant impact on consumer acceptance of foreign brands.

The behavioral factor touches on individual's ability to introduce broad range of verbal and nonverbal action when interacting with people from diverse background (Ang et al., 2007). It lets individuals to control and adjust social behavior in intercultural confront so that there is slightest chance of misunderstanding and misjudgment. Research on intercultural communication documents greatly varies in appropriate modes of communication across cultures. Korzilius, Bucker \& Beerlage (2017) emphasizes that is very important to apply adequate behavior in a certain cultural environment. Consequently, behaviors that are suitable in communicating in one cultural situation may be unsuitable in another (Pratono \& Arli, 2020). Therefore, people need to be adaptable to a different cultural setting. This flexibility in behavior is immensely principal in an intercultural context. The reason is that individuals do not have the quickest access to the notions, feelings, and motivations of others. Instead, they must come to certain conclusions on the basis of non-verbal communication signs such as facial expressions, looks, movements and the like (Caputo, Ayoko \& Amoo, 2018). Cultural al teration is a person's perception in a given situation, because those who have the capacity to change their behavior (behavioral cultural intelligence) will have greater cultural conversion.

Frias-Jamilena et al. (2018a) found that the behavioral factor of cultural intelligence in tourism has a statistically significant positive impact on consumers when choosing foreign destinations. People with a high level of cultural intelligence visit foreign tourists' destinations. They have the desire to communicate with people from other cultures, try the specialties of those countries, enjoy nature and adventures. Such people rarely go to places where they have already been because they have a desire to continuously meet new people, other cultures, and tourist destinations. Also, people with a high level of cultural intelligence buy foreign brands. The above researches form the basis for formulating another hypothesis in the paper:

H2: The behavioral factor of cultural intelligence has a positive statistically significant impact on consumer acceptance of foreign brands. 
Correlation analysis in the research by Gooden, Creque \& Chin-Loy (2017) revealed a positive correlation between the motivational and behavioral factors of intercultural intelligence, establishing that individuals with motivational property will have behavioral propensities. Motivational ability is based on the inherent motivation of an individual (Ang et al., 2007). It means that individuals who are interested in acknowledging cultural diversities, will alter their behavior to adapt to these diversities. Previous research (Baes, 2013) has conducted gender-based testing on cultural intelligence. In the case of the motivational factor, there was analytically notable distinction in the results in the male sex. The motivational aspect of cultural intelligence represents the desire of an individual to contact people from different cultures (Shi \& Shan, 2019). The statistically significant change in the results of this factor between the sexes can be explained by gender differences. This type of research has increased in the last decade and some gender differences are linked to biological and/or sociological causes. Another research has also shown that men adapt better to foreign culture than women (Ornoy, Nishri \& Uziel, 2014), and research by Lee, Veasna \& Wu (2013) shows that individuals with high motivational intelligence adapt better to foreign culture. When these two studies are correlated, it is concluded that the motivational factor of cultural intelligence is more pronounced in men and that they are more readily adapted to foreign culture. Respecting previous empirical research, and to link behavioral and motivational factors of cultural intelligence, a third hypothesis was formulated in this research:

H3: The behavioral factor of cultural intelligence is more pronounced in male than female.

For ease of monitoring and better understanding of the work structure, the conceptual model was formulated and presented in Figure 1.

Figure 1: Research model

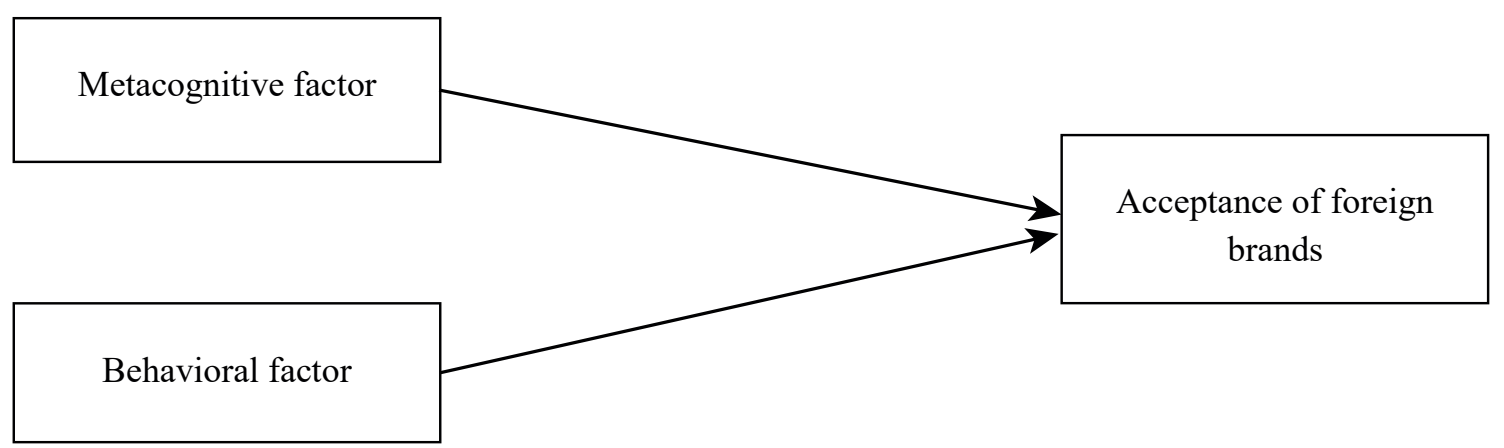




\section{RESEARCH METHODOLOGY}

An empirical study was conducted in January and February 2020 to examine the impact of the metacognitive and behavioral factors of cultural intelligence on foreign brand acceptance. For the collection of primary data, a survey method was used in the form of a questionnaire consisting of 14 statements. Respondents provided answers via a five-point Likert scale and expressed a degree of agreement with a statement of grades 1 to 5 . The findings were taken from relevant papers that previously addressed this issue, which is a common approach in field marketing research (Table 1 provides an overview of the findings used). The total sample size is 114 respondents. The data collected were processed by the SPSS Statistic V.23.

Analysis of the demographic profile of the sample shows that women are dominant gender in the sample. Specifically, the sample contains 48 male respondents (42.1\%) and 66 female respondents (57.9\%). In terms of age, younger respondents (up to 30 years) make up the largest demographic group and have a total of $57.9 \%$ in the sample. Regarding monthly income, the largest percentage of the sample is made up of respondents with monthly income over 50,000 dinars (35.1\%).

Table 1: Research variables and used items

\begin{tabular}{|c|c|c|}
\hline Variable & Items & Source \\
\hline $\begin{array}{l}\text { Metacognitive } \\
\text { factor }\end{array}$ & $\begin{array}{l}\text { 1. I am aware of the cultural knowledge which I use in interaction } \\
\text { with people from different cultural places. } \\
\text { 2. When I interact with people from unrelated cultures I always } \\
\text { try to adjust my cultural knowledge. } \\
\text { 3. I am aware of the cultural ability that I usein intercultural } \\
\text { communication. } \\
\text { 4. I check the level of my cultural ability in interaction with } \\
\text { people with different cultural backgrounds. }\end{array}$ & $\begin{array}{c}\text { Adapted to: } \\
\text { Ang et al. (2007) }\end{array}$ \\
\hline $\begin{array}{l}\text { Behavioral } \\
\text { factor }\end{array}$ & $\begin{array}{l}\text { 5. I change my accent and tone when intercultural situation } \\
\text { demands it. } \\
\text { 6. I use different breaks and silence to respond to specified } \\
\text { cultural demands. } \\
\text { 7. I change the pitch of my speaking when the cultural situation } \\
\text { requires it. } \\
\text { 8. I change my nonverbal abilities when intercultural interaction } \\
\text { demands it. } \\
\text { 9. I change facial expressions depending on the intercultural } \\
\text { situation I am in. }\end{array}$ & $\begin{array}{c}\text { Adapted to: } \\
\text { Ang et al. (2007) }\end{array}$ \\
\hline $\begin{array}{l}\text { Acceptance of } \\
\text { foreign brands }\end{array}$ & $\begin{array}{l}\text { 10. I like to buy foreign branded products. } \\
\text { 11. I buy foreign branded products when there are other products } \\
\text { of the same type. } \\
\text { 12. I delay purchase when I can't find the foreign branded product } \\
\text { I use. } \\
\text { 13. I am ready to set aside a larger sum of money to buy foreign } \\
\text { branded products. } \\
\text { 14. I am ready to recommend to other foreign branded products } \\
\text { that I use. }\end{array}$ & $\begin{array}{c}\text { Adapted to: } \\
\text { Son, Jin \& George } \\
(2013) ; \\
\text { Lee \& Nguyen (2017). }\end{array}$ \\
\hline
\end{tabular}

Source: Author's 


\section{RESEARCH RESULTS}

The study first applied a reliability analysis to determine whether the findings by which certain variables are measured are internally consistent. Table 2 presents the results obtained.

Table 2: Reliability analysis

\begin{tabular}{cc}
\hline Variable & Cronbach's alpha \\
\hline Metacognitive factor & 0.899 \\
\hline Behavioral factor & 0.914 \\
\hline Acceptance of foreign brands & 0.932 \\
\hline
\end{tabular}

Source: Author's

Reliability analysis is usually performed by considering the values of the Cronbach's alpha coefficient. For a variable to have an adequate degree of reliability, it is necessary that the value of this coefficient is higher than 0.70 (Nunnally, 1978), which is realized in the case of the above variables. In the second step, a descriptive statistical analysis was applied. Table 3 reveal the values of arithmetic means (M) and standard deviations (SD) for the used statements.

Table 3: Results of descriptive statistics

\begin{tabular}{|c|c|c|}
\hline Items & M & SD \\
\hline $\begin{array}{l}\text { 1. I am aware of the cultural knowledge which I use in interaction with people from } \\
\text { different cultural places. }\end{array}$ & 2.27 & 0.91 \\
\hline $\begin{array}{l}\text { 2. When I interact with people from unrelated cultures Ialways try to adjust my cultural } \\
\text { knowledge. }\end{array}$ & 2.97 & 1.42 \\
\hline 3. I am aware of the cultural ability that I use in intercultural communication. & 3.5 & 0.88 \\
\hline $\begin{array}{l}\text { 4. I check the level of my cultural abilityin interaction with people with different cultural } \\
\text { backgrounds. }\end{array}$ & 3.26 & 1.04 \\
\hline 5. I change my accent and tone when intercultural situation demands it. & 2.97 & 1.32 \\
\hline 6. I use different breaks and silence to respond to specified cultural demands. & 2.82 & 1.89 \\
\hline 7. I change the pitch of my speaking when the cultural situation requires it. & 2.96 & 1.62 \\
\hline 8. I change my nonverbal abilities when intercultural interaction demands it. & 2.96 & 1.43 \\
\hline 9. I change facial expressions depending on the intercultural situation I am in. & 2.98 & 1.51 \\
\hline 10. I like to buy foreign branded products. & 2.83 & 1.46 \\
\hline 11. I buy foreign branded products when there are other products of the same type. & 3.11 & 1.65 \\
\hline 12. I delay purchase when I can't find the foreign branded product I use. & 3.54 & 1.69 \\
\hline 13. I am ready to set aside a larger sum of money to buy foreign branded products. & 2.96 & 1.61 \\
\hline 14. I am ready to recommend to other foreign branded products that I use. & 3.39 & 1.41 \\
\hline
\end{tabular}


Respondents expressed the most favorable attitudes on the basis of the statement "I delay purchase when I can't find the foreign branded product I use" (the highest arithmetic mean 3.54), while the most unfavorable attitudes the respondents expressed on the basis of the statement "I am aware of the cultural knowledge which I use in interaction with people from different cultural places" (lowest value of arithmetic mean 2.27). Respondent's attitudes are the most homogeneous based on the statement "I am aware of the cultural ability that I use in intercultural communication" (the lowest standard deviation value is 0.88). Respondent's attitudes are the least homogeneous based on statement "I use different breaks and silence to respond to specified cultural demands" (highest standard deviation value 1.89). Table 4 shows the results of the correlation analysis.

Table 4: Results of correlation analysis

\begin{tabular}{cccc}
\hline & $\begin{array}{c}\text { Metacognitive } \\
\text { factor }\end{array}$ & $\begin{array}{c}\text { Behavioral } \\
\text { factor }\end{array}$ & $\begin{array}{c}\text { Acceptance of } \\
\text { foreign brands }\end{array}$ \\
\hline Metacognitive factor & 1 & $0.328^{*}$ & $0.422^{*}$ \\
\hline Behavioral factor & $0.328^{\star}$ & 1 & $0.659^{*}$ \\
\hline $\begin{array}{c}\text { Acceptance of } \\
\text { foreign brands }\end{array}$ & $0.422^{*}$ & $0.659^{*}$ & 1 \\
\hline
\end{tabular}

Source: Author's

Note: * coefficients are statistically significant at the level 0.01

The results show that all values of Pearson's linear correlation coefficient are statistically significant. The behavioral factor of cultural intelligence has a greater association with foreign brand acceptance than the metacognitive factor of cultural intelligence.

Table 5 presents the results of multiple regression analyzes, which measured the impact of the metacognitive and behavioral factors of cultural intelligence on foreign brand acceptance.

Table 5: Results of multiple regression analysis (dependent variable: Acceptance of foreign brands)

\begin{tabular}{cccc}
\hline & $\boldsymbol{\beta}$ & Sig. & VIF \\
\hline Metacognitive factor & 0.124 & 0.217 & 1.526 \\
\hline Behavioral factor & $0.386^{*}$ & 0.001 & 1.386
\end{tabular}

Source: Author's

Note: * coefficients are statistically significant at the level $0.01 ; R 2=0.448$

The coefficient of determination $\left(\mathrm{R}^{2}\right)$ is 0.448 , which means that $44.8 \%$ of the variability of acceptance of foreign brands is explained by this regression model. The data are appropriate for conducting multiple regression analysis because the value of the VIF coefficient in all pairs is less than 5 , so there is no problem of multicollinearity (Field, 2000). Based on the presented results, it is concluded that the behavioral factor of cultural intelligence has a statistically significant influence on the acceptance of foreign brands $(\beta=0.386, \mathrm{p}<0.01$ ), while the influence of the metacognitive factor is not statistically significant $(\beta=0.124, \mathrm{p}>0.01)$. Based on the above, it can be concluded that hypothesis $\mathrm{H} 1$ was not confirmed, while hypothesis $\mathbf{H} 2$ was confirmed. For testing the third hypothesis, a $T$ test was conducted for two independent samples, through which the expression of behavioral factor was analyzed based on the gender criterion (Table 6). 


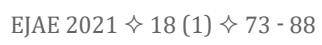
ZDRAVKOVIĆ. S., PEKOVIĆ. J. ^ ATHE IMPACT OF THE METACOGNITIVE AND BEHAVIORAL FACTORS OF CULTURAL INTELLIGENCE ON FOREIGN BRAND ACCEPTANCE

Table 6: Results of $T$ test for two independent samples: the criterion for comparison is gender of respondents

\begin{tabular}{|c|c|c|c|c|c|c|}
\hline \multirow[t]{2}{*}{ Factor name } & \multicolumn{2}{|c|}{ Women } & \multicolumn{2}{|c|}{ Man } & \multirow[t]{2}{*}{$\mathbf{T}$} & \multirow[t]{2}{*}{ sig. } \\
\hline & AS & SD & AS & SD & & \\
\hline $\begin{array}{l}\text { 1. I change my accent and tone when inter- } \\
\text { cultural situation demands it. }\end{array}$ & 2.95 & 1.59 & 3.00 & 0.84 & -0.184 & 0.850 \\
\hline $\begin{array}{l}\text { 2. I use different breaks and silence to } \\
\text { respond to specified cultural demands. }\end{array}$ & 2.94 & 2.01 & 2.67 & 1.71 & 0.768 & 0.444 \\
\hline $\begin{array}{l}\text { 3. I change the pitch of my speaking when } \\
\text { the cultural situation requires it. }\end{array}$ & 2.94 & 2.01 & 3.00 & 0.84 & -0.208 & 0.835 \\
\hline $\begin{array}{l}\text { 4. I change my nonverbal abilities when } \\
\text { intercultural interaction demands it. }\end{array}$ & 2.45 & 1.34 & 3.67 & 0.95 & $-5.067^{\star}$ & 0.000 \\
\hline $\begin{array}{l}\text { 5. I change facial expressions depending } \\
\text { on the intercultural situation I am in. }\end{array}$ & 3.45 & 1.51 & 2.33 & 1.26 & $4.249^{\star}$ & 0.000 \\
\hline$\Sigma \mathrm{BH}$ Behavioral factor of cultural intelligence & 2.95 & 1.69 & 2.93 & 1.12 & -0.442 & 0.709 \\
\hline
\end{tabular}

Source: Author's

Note: * coefficients are statistically significant at the level 0.01

The results of the $t$ test for the two independent samples shown in Table 6, it is evident that for the first three findings there is no statistically significant difference in the behavioral factor of cultural intelligence among men compared to women. However, forth statement "I change my nonverbal abilities when intercultural interaction demands it" and in fifth statement "I change facial expressions depending on the intercultural situation I am in", statistically significant differences between women and men occur. With the fourth statement "I change my nonverbal abilities when intercultural interaction demands it" men agree to a greater extent (arithmetic mean 3.67) than women (arithmetic mean 2.45). Also, regarding this statement, men also have more homogeneous views, which show a lower standard deviation value of 0.95 , while this value in women is 1.34 . In the fifth statement "I change facial expressions depending on the intercultural situation I am in", women agree to a greater extent (arithmetic mean is 3.45) than men (arithmetic mean is 2.33). But, based on standard deviation data that women's attitudes in this statement are more heterogeneous (standard deviation is 1,51) compared to men's attitudes (standard deviation is 1,26$)$.

Comparing the summary data for arithmetic means for women and men, it is concluded that there is no statistically significant difference in the expression of behavioral cultural intelligence factors for women and men, and that the gender factor has no effect ( 2.95 for women, while for men the arithmetic mean is 2.93). Based on the above, it can be concluded that hypothesis $\mathbf{H} 3 \mathbf{~ h a s ~ n o t ~ b e e n ~ c o n f i r m e d . ~}$

\section{CONCLUSION}

Through terminological definition and analysis of metacognitive and behavioral factors of cultural intelligence, the aim was to determine how metacognitive and behavioral factors of cultural intelligence influence the acceptance of foreign brands. Also, the aim is to determine how these findings can help multinational companies in shaping and presenting their brands so that they are better accepted in different cultural environments. Despite the need to improve the ability to work and function in other intercultural environments to reach multinational company brands with greater reach and response from 
consumers in different cultural settings, the effect of metacognitive and behavioral cultural intelligence factors on foreign brand acceptance has been addressed in a small number of worldwide research, and especially in the territory of the Republic of Serbia, which poses $s$ a key originality and contribution of this work. The theoretical implications of the paper are reflected in the expansion of existing knowledge about the influence of the metacognitive and behavioral factor of cultural intelligence on the acceptance of foreign brands and its results can be used for further research in this field.

Three hypotheses were put forward in the paper. The results of multiple regression analyzes showed that the metacognitive factor of cultural intelligence had no statistically significant influence on foreign brand acceptance, thus refuting hypothesis H1. Also, the results of the same analysis showed that the behavioral factor of cultural intelligence had a statistically significant effect on the acceptance of foreign brands, thus confirming hypothesis $\mathrm{H} 2$. The results of the T test indicated that the behavioral factor of cultural intelligence was equally represented in both sexes, thus refuting the $\mathrm{H} 3$ hypothesis, which suggested that the behavioral factor of cultural intelligence was more pronounced in men. The first hypothesis sought to determine whether the metacognitive factor of intercultural intelligence influences foreign brand acceptance. The results of the multiple regression analyzes showed that the metacognitive factor had no statistically significant influence on the acceptance of foreign brands, thus refuting the hypothesis $\mathrm{H} 1$ and not confirming the results of previously conducted empirical studies that showed the influence of the metacognitive element of cultural intelligence on the acceptance of foreign brands (Frias-Jamilena et al., 2018b; Pratono \& Arli, 2020). Previous research (Pratono \& Arli, 2020) has also shown that metacognitive abilities grow as a function of age that is, with aging, they are able to adapt to new situations and things. Taking into account research results in this study, it is concluded that the results were performed by statistical analyses showing that the metacognitive factor of cultural intelligence does not affect the acceptance of foreign brands, resulting from the fact that the majority of the sample are young respondents and middle-aged respondents.

A second hypothesis was defined to identify whether the behavioral factor of cultural intelligence influences foreign brand acquisition. Given that cultural adjustment is a person's sense of fit in a given situation, multiple regression analyses have shown that those individuals with a higher degree of ability to change their behavior in different cultural settings (behavioral cultural intelligence) will be more willing to embrace brands that come from foreign countries, as confirmed by previous empirical research (Frias-Jamilena et al., 2018a; Pratono \& Arli, 2020). This confirms the hypothesis H2.

A third hypothesis has been put forward to determine whether the behavioral factor of cultural intelligence is more pronounced in men. Specifically, the hypothesis is based on an individual's intermotivation, which states that individuals who are interested in acknowledging cultural diversities, will alter their behavior to adapt to these diversities (Ang et al., 2007), as well as previous empirical research that has shown that men adapt better to foreign culture than women (Ornoy, Nisri \& Uziel, 2014). However, after the $\mathrm{T}$ test, the result showed that the behavioral factor of cultural intelligence was not more pronounced in men, but that it was the same in both sexes, that is, the sexuality of the behavioral factor did not depend on gender, thus rejecting hypothesis H3. This was only confirmed by previous research (Baes, 2013) where in the case of cognitive, metacognitive, and behavioral factors there was no statistically significant difference in scores between men and women.

The results of the empirical research conducted have important practical implications. The results obtained confirm the view that the behavioral factor of cultural intelligence influences the acceptance of foreign brands. This knowledge can help multinational companies in shaping their brands, so that when they enter culturally different markets, they have better acceptance of their brands with consumers. 
This implies that as companies continue their operations in the international market, the behavioral factor of cultural intelligence will play an essential part in their success. In different circumstances, the metacognitive factor of cultural intelligence did not show statistical significance in the acceptance of foreign brands. Bearing in mind that metacognitive abilities increase with aging, and that less than a third of respondents in the work belonged to the older age, it can be implied that the statistically negative result was due to the sample where the demographic group represented the younger age group.

Also, an important implication is that there are no dissimilarities in the behavioral factor of cultural intelligence between different genders. Psychology has shown that behavioral modeling can influence the behavior of participants by subverting behavior that leads to the desired goal, in this case the acceptance of foreign products. Since there is no difference in behavior between men and women, this can be used to encourage desired consumer behavior that will lead to the achievement of the goals of multinational companies.

Despite its contribution, the research conducted for the purpose of this paper has several limitations, which at the same time provides directions for future research. First limitation is a small sample of respondents with a total of 114 respondents. Compared to the surveys previously conducted in this area, there is a need to enlarge the number of interviewed respondents. Another limitation is that the survey was conducted using a survey method where there is a danger of giving socially desirable answers. The third limitation is the absence of the remaining two factors (cognitive and motivational factors) that, in addition to the metacognitive and behavioral factors, form an integral part of cultural intelligence. I Infuture studies authors should use other factors.

\section{REFERENCES}

Ang, S., Van Dyne, L., Koh, C., Ng, K.Y., Templer, K. J., Tay, C., \& Chandrasekar, N.A. (2007). Cultural Intelligence: Its Measurement and Effects on Cultural Judgment and Decision Making, Cultural Adaptation and Task Performance. Management and Organization Review, 3, 335-371. DOI: 10.1111/j.1740-8784.2007.00082.x

Ang, S., \& Van Dyne, L. (2015). Handbook of Cultural Intelligence. Routledge, London.

Alon, I., Boulanger, M., Meyers, J., \& Taras, V. (2016). The development and validation of the Business Cultural Intelligence Quotient. Cross cultural \& Strategic Management, 23(1), 78-100. DOI:10.1108/CCSM-102015-0138

Aldhaheri, A. (2017). Cultural intelligence and leadership style in the education sector. International Journal of Educational Management, 31(6), 718-735. DOI:10.1108/IJEM-05-2016-0093

Alshaibani, E., \& Bakir, A. (2017). A reading in cross-cultural service encounter: Exploring the relationship between cultural intelligence, employee performance and service quality. Tourism and Hospitality Research, 17(3), 249-263. DOI:10.1177/1467358416651474

Afsar, B., Shahjehan, A., Imad Shah, S., \& Wajid, A. (2019). The mediating role of transformational leadership in the relationship between cultural intelligence and employee voice behavior: A case of hotel employees. International Journal of Intercultural Relations, 69, 66-75. DOI:10.1016/j.ijintrel.2019.01.001

Baes, D. (2013). Cultural Intelligence in foreign language classes. Indiana: Indiana state University.

Chailan, C., \& Ille, F. (2015). Branding from emerging countries: how to compete internationally. Critical perspectives on international business, 11(1), 54-71. DOI:10.1108/cpoib-11-2012-0055

Caputo, A., Ayoko, O.B., \& Amoo, N. (2018). The moderating role of cultural intelligence in the relationship between cultural orientations and conflict management styles. Journal of Business Research, 89 (August 2018), 10-20. DOI:10.1016/j.jbusres.2018.03.042

Field, A. (2000). Discovering statistics using SPSS for Windows. Thousand Oaks: Sage Publication. 
Frias-Jamilena, D. M., Sabiote-Ortiz, C.M., Martin-Santana, J.D., \& Beerli-Palacio, A. (2018a). Antecedents and consequences of cultural intelligence in tourism. Journal of Destination \& Marketing, 8, 350-358. DOI:10.1016/j.jdmm.2017.07.006

Frias-Jamilena, D. M., Sabiote-Ortiz, C. M., Martin-Santana, J. D., \& Beerli-Palacio, A. (2018b). The effect of cultural Intelligence on consumer-based destination brand equity. Annals of Tourism Research, 72, 22-36. DOI:10.1016/j.annals.2018.05.009

Gooden J., Creque, C.A., \& Chin-Loy, C. (2017). The impact of metacognitive, cognitive, and motivational cultural intelligence on behavioral cultural intelligence. International Business \& Economics Journal, 16(3), 223-230. DOI:10.19030/iber. v 16i3.10006

Helen Kurpis, L., \& Hunter, J. (2017). Developing Students' Cultural Intelligence Through an Experiential Learning Activity: A Cross-Cultural Consumer Behavior Interview. Journal of Marketing Education, 39(1), 30-46. DOI:10.1177/0273475316653337

Hu, S., Gu, J., Liu, H., \& Huang, Q. (2017). The moderating role of social media usage in the relationship among multicultural experiences, cultural intelligence, and individual creativity. Information Technology and People, 30(2), 265-281. DOI:10.1108/ITP-04-2016-0099

Han, C.M., \& Guo, C. (2018). How Consumer Ethnocentrism (CET), Ethnocentric Marketing, and Consumer Individualism Affect Ethnocentric Behavior in China. Journal of Global Marketing, 31(5), 324-338. DOI:10.1080/08911762.2018.1437649

Iversen, N.M., \& Hem, L.E. (2011). Reciprocal transfer effects for brand extensions of global or local origin:evidence from Norway. International Marketing Review, 28(4), 365-411. DOI:10.1108/02651331111149949

Jyoti, J., \& Kour, S. (2015). Assessing the cultural intelligence and task performance equation: Mediating role of cultural adjustment. Cross Cultural Management: An International Journal, 22(2), 236-258. DOI:10.1108/ CCM-04-2013-0072

Korzilius, H., Bucker, Joost J.L.E., \& Beerlage, S. (2017). Multiculturalism and innovative work behavior: The mediating role of cultural intelligence. International Journal of Intercultural Relations, 56, 13-24. DOI:10.1016/j. ijintrel.2016.11.001

Kovačić, S., Milenković, N., Slivar, I., \& Rancic, M. (2019). Shaping city brand strategies based on the tourists' brand perception: report on Banja Luka main target groups. International Journal of Tourism Cities, 6(2), 371-396. DOI:10.1108/IJTC-08-2018-0061

Lee, L., Veasna, S., \& Wu, W. (2013). The effects of social support and transformational leadership on expatriate adjustment and performance: The moderating roles of socialization experience and cultural intelligence. Career Development International, 18(4), 377-415. DOI:10.1108/CDI-06-2012-0062

Lee, J., \& Nguyen, M. J. (2017). Product attributes and preference for foreign brands among Vietnamese consumers. Journal of Retailing and Consumer Services, 35, 76-83. DOI: 10.1016/j.jretconser.2016.12.001

Lorenz, M., Ramsey, J., \& Richey, R.G. (2018). Expatriates' international opportunity recognition and innovativeness: The role of metacognitive and cognitive cultural intelligence. Journal of World Business, 53(2), 222-236. DOI: $10.1016 /$ j.jwb.2017.11.004

Li, M. (2020). An examination of two major constructs of cross-cultural competence: Cultural intelligence and intercultural competence. Personality and Individual Differences, 164, 110105. DOI: 10.1016/j.paid.2020.110105

Moon, T. (2010). Emotional intelligence correlates of the four-factor model of cultural intelligence. Journal of Managerial Psychology, 25(8), 876-898. DOI:10.1108/02683941011089134

Mandler, T. (2019). Beyond reach: an extended model of global brand effects. International Marketing Review, 36(5), 647-674. DOI:10.1108/IMR-01-2018-0032

Nunnally, J. C. (1978). Introduction to psychological measurement. New York: McGraw-Hill.

Nicic, M., \& Iguman, S. (2019). Post-socialism and "ordinary" tourism: New Belgrade. International Journal of Tourism Cities, 5(3), 307-325. DOI:10.1108/IJTC-01-2018-0002. 
Ornoy, H., Nishri, G. L., \& Uziel, L. (2014). Relationship between the Personality and Gender and the Adjustment to a Foreign Culture: Comparative Research between Expatriates and Business Trip Travelers. International Journal of Business Administration, 5, 122-134. DOI:10.5430/ijba.v5n3p122

Pratono, A.H., \& Arli, D. (2020). Linking global consumer culture and ethnocentric consumerism to global citizenship: exploring the mediating effect of cultural intelligence. International Journal of Sociology and Social Policy, 40(7/8), 659-675. DOI:10.1108/IJSSP-10-2019-0212

Rookwood, J. (2019). Access, security, and diplomacy: perceptions of soft power, nation branding and the organizational challenges facing Qatar's 2022 FIFA World Cup. Sport, Business and Management, 9(1), 26-44. DOI:10.1108/SBM-02-2018-0016

Sarkar, A. N. (2012). Green Branding and Eco-innovations for Evolving a Sustainable Green Marketing Strategy. AsiaPacific Journal of Management Research and Innovation, 8(1), 39-58. DOI: 10.1177/2319510X1200800106

Son, J., Jin, B., \& George, B. (2013). Consumers' purchase intention toward foreign brand goods. Management Decision, 51(2), 434-450. DOI:10.1108/00251741311301902

Shi, X., \& Shan, X. (2019). Cross-cultural impact on financial company's online brand personality. Marketing Intelligence \& Planning, 37(5), 482-496. DOI:10.1108/MIP-06-2018-0233

Shaik, F.F., Makhecha, U.P., \& Gouda, S.K. (2020). Work and non-work identities in global virtual teams: Role of cultural intelligence in employee engagement. International Journal of Manpower, 42(1), 51-78. DOI:10.1108/IJM-03-2019-0118

Tuan, L.T. (2016). From cultural intelligence to supply chain performance. International Journal of Logistic Management, 27(1), 95-121. DOI:10.1108/IJLM-01-2014-0009

Thomas R., \& Van Dyne, L. (2018). A bi-factor theory of the four-factor model of cultural intelligence: metaanalysis and theoretical extensions. Organizational Behavior and Human Decision Processes, 148, 124-144. DOI: 10.1016/j.obhdp.2018.07.005

Vlajcic, D., Marzi, G., Caputo, A., \& Dabic, M. (2019). The role of geographical distance on the relationship between cultural intelligence and knowledge transfer. Business Process Management Journal, 25(1), 104-125. DOI:10.1108/BPMJ-05-2017-0129

Zabkar, V., Arslanagic-Kalajdzic, M., Diamantopoulos, A., \& Florack, A. (2017). Brothers in blood, yet strangers to global brand purchase: A four-country study of the role of consumer personality. Journal of Business Research, 80, 228-235. DOI: 10.1016/j.jbusres.2017.06.006

Zhou, C., Hu, N., Wu, J., \& Gu, J. (2018). A new scale to measure cross-organizational cultural intelligence: Initial development and validation. Chinese Management Studies, 12(3), 658-679. DOI:10.1108/CMS-10-2017-0309 


\section{UTICAJ FAKTORA PONAŠANJA I METAKOGNITIVNIH FAKTORA KULTURNE INTELIGENCIJE NA PRIHVAĆENOST STRANOG BRENDA}

\section{Rezime:}

Cilj rada je da pokaže uticaj kulturne inteligencije na prihvatanje stranih brendova i kako ti uvidi mogu pomoći multinacionalnim kompanijama u oblikovanju i predstavljanju svojih brendova kako bi bili bolje prihvaćeni u različitim kulturnim sredinama. Kulturna inteligencija sastoji se od četiri faktora, od kojih su dva analizirana za potrebe ovog rada - metakognitivni faktori i faktori ponašanja. Metakognitivne kulturne dimenzije su korisne za pojedinca da bi se steklo određeno znanje o nekoj kulturi. Kulturna inteligencija u ponašanju predstavlja sposobnost prilagođavanja pojedinca verbalnom i neverbalnom ponašanju u skladu sa situacijom u kulturno raznolikim sredinama. Rezultati empirijskog istraživanja pokazali su statistički značajan pozitivan uticaj bihejvioralnog elementa kulturne inteligencije na prihvatanje stranih brendova od strane potrošača, dok uticaj metakognitivnih faktora na prihvatanje stranih brendova nije statistički značajan, što se razlikuje od većine prethodno sprovedenih empirijskih studija.
Ključne reči:

kulturna inteligencija, metakognitivni faktori, faktori ponašanja, strani brend.

Klasifikacija jela:

D91, Z13 